\title{
YIELD OF INBRED AND HYBRID RICE AS AFFECTED BY CLONAL TILLERS OF SUCCESSIVE GENERATION
}

\author{
P. K. Hore ${ }^{1^{\star}}$, P. K. Biswas ${ }^{1}$, A. K. M. R. Amin ${ }^{1}$, Raziuddin ${ }^{2}$, M. S. Mahmud ${ }^{3}$ S. M. Mohsin ${ }^{4}$ \\ ${ }^{1}$ Department of Agronomy, Sher-e-Bangla Agricultural University, Dhaka-1207, Bangladesh \\ ${ }^{2}$ Scientific Officer, Regional Agricultural Research Station, BARI, Rahamatpur, Barishal, Bangladesh \\ ${ }^{3}$ Research Associate, Collection, Evaluation and Introduction of White Maize for Human Consumption \\ in Bangladesh, Sher-e-Bangla Agricultural University, Dhaka, Bangladesh \\ ${ }^{4}$ Department of Plant Pathology, Sher-e-Bangla Agricultural University, Dhaka-1207, Bangladesh \\ ${ }^{*}$ Corresponding Author: shuvosau@gmail.com
}

Key Words: Yield, clonal tillers, rice Key Words: Inbred, hybrid, clonal tillers, yield

\begin{abstract}
A field experiment was conducted at the Agronomy field, Sher-e-Bangla Agricultural University, Dhaka from November 2012 to July 2013. Experiment consisted of two factors, viz. (i) variety- BRRI dhan29 $\left(\mathrm{V}_{1}\right)$ and $\mathrm{BRRI}$ hybrid dhan2 $\left(\mathrm{V}_{2}\right)$, and (ii) planting materials- nursery seedlings $(\mathrm{N})$, first generation clonal tillers $\left(\mathrm{C}_{1}\right)$ collected from $\mathrm{N}$, second generation clonal tillers $\left(\mathrm{C}_{2}\right)$ collected from $\mathrm{C}_{1}$, third generation clonal tillers $\left(\mathrm{C}_{3}\right)$ collected from $\mathrm{C}_{2}$ and fourth generation clonal tillers $\left(\mathrm{C}_{4}\right)$ collected from $\mathrm{C}_{3}$, following split-plot design with three replications. Results revealed that despite higher (161.29) number of filled grains as obtained from BRRI dhan29 while lower (139.31) from BRRI hybrid dhan2, and maximum weight of 1000-grains $(26.50 \mathrm{~g})$ from hybrid variety and the minimum from the inbred one $(19.70 \mathrm{~g})$, the grain yield was not varied significantly. Among the planting materials nursery seedlings gave the maximum $\left(9.23 \mathrm{t} \mathrm{ha}^{-1}\right)$ grain yield that followed by first generation clonal tillers $\left(7.44 \mathrm{tha}^{-1}\right)$, and second generation clonal tillers $\left(6.57 \mathrm{t} \mathrm{ha}^{-1}\right)$. The third and fourth generation clonal tillers also produced around $3 \mathrm{t} \mathrm{ha}^{-1}$ grain yield. The maximum grain yield $\left(9.6 \mathrm{t} \mathrm{ha}^{-1}\right)$ was observed from the combination of nursery seedlings with BRRI hybrid dhan2 which is statistically similar to the combination of same planting material with BRRI dhan29 $\left(8.86 \mathrm{t} \mathrm{ha}^{-1}\right)$. The first and second generation clonal tillers of both the varieties produced more than $6.0 \mathrm{t} \mathrm{ha}^{-1}$ grain yield. Therefore, clonal tillers can be used as planting materials for both hybrid and inbred rice cultivation in case of scarce supply of nursery seedlings.
\end{abstract}

\section{Introduction}

Bangladesh is the fourth highest rice (Oryza sativa L.) producing country in the world (FAO, 2013). About $76.71 \%$ of the total cropped area was planted with rice in 2012-13. Total rice production in Bangladesh was about 10.59 million tons in 1971 when the country's population was only about 70.88 million. However, the country is now producing about 34.00 million tons to feed her 149.69 million people (Mondal and Choudhury, 2014). Rice yield therefore, needs to be increased from the present 2.74 to $3.74 \mathrm{t} \mathrm{ha}^{-1}$ (BRRI, 2011) but there is a little scope to increase rice area. Moreover, the arable land is decreasing at the rate of $1 \%$ per annum (BBS, 2011). In such situation, there is no other alternative rather than development and adoption of yield enhancing technologies. To get higher productivity, hybrid rice is an important option which contribute $20-30 \%$ yield advantage over inbred varieties (Julfiquar et al., 2009). Hossain et al. (2003) reported that hybrid rice has the potentiality to increase $15-20 \%$ yield but it costs about $19 \%$ higher compared to inbred rice of which seed cost is the prime issue. Among different groups of rice, boro season covers 
Hore et al.

about $43.57 \%$ of total rice area which contributes $61.33 \%$ of the total rice production (BBS, 2008), but this rice production is affected by various biotic and abiotic constraints. Damage of seedling in the seedbed due to cold has been identified as a constraint. In this perspective separation of tillers from rice plants could escape cold damage and replanting of the separated tillers to the new rice fields may be vital alternatives for growing boro rice (Mamun et al., 2012). The detached tillers can be used as seedling, especially during scarcity of seedlings after flood or any other natural hazards (Biswas, 2001). It is possible to transplant the separated tillers in the prepared main field those have the potentiality to produce yield as main crop (Debnath, 2010). Beside this, use of rice clonal tillers might be an option for maximum yield and reduce seed cost especially hybrid rice (Debnath, 2010). As hybrid rice seeds are costly and scarce, successful use of their clonal tillers can help to reduce seed cost as well as expansion of hybrid rice cultivation area in Bangladesh. On the other hand, the potentiality of inbred clonal tillers is reported by many researchers (Biswas, 2001; Biswas and Saloke, 2001; Parveen et al., 2008; Hossain et al., 2011; Sarkar et al., 2011; Alim and Sheuly, 2012). Therefore, the present study with an inbred and a hybrid variety of boro rice was undertaken to compare the yield performance of the crop grown from their inbred and hybrid clonal tillers of successive generation and nursery seedlings.

\section{Materials and Methods}

The experiment was conducted at the Agronomy field of Sher-e-Bangla Agricultural University, Dhaka-1207 during the period from December 2012 to July 2013. The experimental area was situated at $23^{\circ} 77^{\prime} \mathrm{N}$ latitude and $90^{\circ} 33^{\prime} \mathrm{E}$ longitude at an altitude of 8.6 meter above sea level (Anon., 2004) belongs to the Agro-ecological zone of "The Modhupur Tract", AEZ-28 (Anon., 1988). The experiment was comprised of variety $\left(\mathrm{V}_{1}=\right.$ BRRI dhan29 and $\mathrm{V}_{2}=\mathrm{BRRI}$ hybrid dhan2) and planting materials $\left(\mathrm{N}=\right.$ nursery seedlings, $\mathrm{C}_{1}$ = first generation clonal tillers collected from, $\mathrm{C}_{2}=$ second generation clonal tillers collected from $\mathrm{C}_{1}, \mathrm{C}_{3}$ = third generation clonal tillers collected from $\mathrm{C}_{2}$ and $\mathrm{C}_{4}=$ fourth generation clonal tillers collected from $\mathrm{C}_{3}$ ). The experiment was laid in a split-plot design with three replications having variety in the main plots and planting materials in the sub-plots. The size of unit plot was $5.0 \mathrm{~m}$ by $2.0 \mathrm{~m}$. Seeds were sown on the seedbed on November 12, 2013 for raising nursery seedlings. 33 days old nursery seedlings were uprooted carefully on December 15, 2012 and were kept in soft mud in shade. The seedlings were then transplanted with $25 \mathrm{~cm} \times 15 \mathrm{~cm}$ spacing on the well-puddled plots. Two sub-plots in each main plot was transplanted with nursery seedlings of which the entire hills of one plot was uprooted and splitted for using as first generation clonal tilletrs. The separated tillers were then re-transplanted as per treatment having one clonal tiller per hill on 30 January, 2013. Second generation $\left(C_{2}\right)$ clonal tillers were separated from $C_{1}$ plants at 30 DAT and the separated tillers were then re-transplanted as per treatment having one clonal tiller hill ${ }^{-1}$ on 2 March, 2013. Third generation $\left(C_{3}\right)$ clonal tillers were separated from $C_{2}$ plants as earlier at 25 DAT and the separated tillers were then re-transplanted as per treatment having one clonal tiller per hill on 27 March, 2013. Lastly the fourth generation $\left(\mathrm{C}_{4}\right)$ clonal tillers were separated from $\mathrm{C}_{3}$ plants at 20 DAT and the separated tillers were then re-transplanted as per treatment having one clonal tiller hill $^{-1}$ on 17 April, 2013. Before re-transplanting, the individual plots were spaded properly for well puddle and an extra dose of urea (one third of basal) was top dressed after seven days of re-transplanting on uprooted plots and entire basal dose for newly transplanted plots. Maturity of crop was determined when $90 \%$ of the grains become golden yellow in color. The harvesting of BRRI dhan29 was done on May 12; Jun 3; Jun 14; Jul 1, 2013 for nursery seedlings $(N)$ and first generation clonal tiller $\left(C_{1}\right)$; second generation clonal tiller $\left(\mathrm{C}_{2}\right)$; third generation clonal tiller $\left(\mathrm{C}_{3}\right)$ and fourth generation 
Yield of Inbred and Hybrid Rice as Affected by Clonal Tillers of Successive Generation

clonal tiller $\left(\mathrm{C}_{4}\right)$, respectively and the harvesting of BRRI hybrid dhan2 was done on May 4; May 21; Jun 14; Jul 1, 2013 for nursery seedlings $(N)$ and first generation clonal tiller $\left(C_{1}\right)$; second generation clonal tiller $\left(\mathrm{C}_{2}\right)$; third generation clonal tiller $\left(\mathrm{C}_{3}\right)$ and fourth generation clonal tiller $\left(\mathrm{C}_{4}\right)$, respectively. The grains were cleaned and sun dried to moisture content of about $12 \%$. Straw was also sun dried properly. Finally grain and straw yields plot $^{-1}$ were recorded and converted to $\mathrm{t} \mathrm{ha}^{-1}$. All the data collected on different parameters were statistically analyzed and the mean differences were adjudged by least significant difference (LSD) test at $5 \%$ level of significance (Gomez and Gomez, 1984).

\section{Results and Discussion}

\section{Effect of variety}

Among yield contributing characters related to grain yield. panicle length, filled and unfilled grains panicle ${ }^{-1}$, and weight of 1000-grain were significantly influenced by the variety (Table 1). The highest $(26.79 \mathrm{~cm})$ and lowest $(22.77 \mathrm{~cm})$ panicle length were obtained from BRRI dhan29 and BRRI hybrid dhan2, respectively. Ahmed (2010) also observed maximum panicle length in BRRI dhan29 than hybrid variety and Debnath (2012) found the highest panicle length in BRRI dhan29 and lowest in BRRI hybrid dhan2 among other varieties. The number of filled grains panicle ${ }^{-1}$ differed significantly for variation of the variety. Higher number of filled grains panicle ${ }^{-1}(161.29)$ was found from inbred variety BRRI dhan29 and lower number of filled grains panicle ${ }^{-1}(139.31)$ from BRRI hybrid dhan2. Higher number of unfilled grains panicle ${ }^{-1}$ (51.53) was found from inbred variety BRRI dhan29 and lower number of unfilled grains panicle ${ }^{-1}$ (8.52) from BRRI hybrid dhan2. This finding similar with Debnath (2010) who found the highest number of unfilled grains panicle ${ }^{-1}$ from the inbred variety BRRI dhan29 than hybrid variety BRRI hybrid dhan2 though Obaidullah (2007) observed the highest number of unfilled grains panicle ${ }^{-1}$ in the hybrid variety and the lowest in the inbred variety. The maximum $(26.50 \mathrm{~g})$ weight of 1000 -grains was obtained from BRRI hybrid dhan2 and the minimum $(19.70 \mathrm{~g})$ weight from BRRI dhan29. The result supports the findings of Obaidullah (2007), Ashrafuzzaman (2006) and Debnath (2010) who found the highest weight of 1000-grains in hybrid variety than the inbred variety BRRI dhan29.

Table 1. Effect of variety on yield and other crop characters related to yield of two rice varieties

\begin{tabular}{cccccccccc}
\hline Treatments & $\begin{array}{c}\text { Effective } \\
\text { tillers } \\
\left(\text { no. }^{-2}\right)\end{array}$ & $\begin{array}{c}\text { Ineffective } \\
\text { tillers } \\
\left(\text { no. } \mathrm{m}^{-2}\right)\end{array}$ & $\begin{array}{c}\text { Panicle } \\
\text { length } \\
(\mathrm{cm})\end{array}$ & $\begin{array}{c}\text { Filled } \\
\text { grains } \\
\text { panicle } \\
(\text { no. })\end{array}$ & $\begin{array}{c}\text { Unfilled } \\
\text { grains } \\
\text { panicle } \\
(\text { no. })\end{array}$ & $\begin{array}{c}1000- \\
\text { grains } \\
\text { weight } \\
(\mathrm{g})\end{array}$ & $\begin{array}{c}\text { Grain } \\
\text { yield } \\
(\mathrm{t} \mathrm{ha} \\
\left.{ }^{1}\right)\end{array}$ & $\begin{array}{c}\text { Straw } \\
\text { yield } \\
\left(\mathrm{t} \mathrm{ha}^{-1}\right)\end{array}$ & $\begin{array}{c}\text { Harvest } \\
\text { index } \\
(\%)\end{array}$ \\
\hline $\mathrm{V}_{1}$ & 234.27 & 24.99 & $26.79 \mathrm{a}$ & $161.29 \mathrm{a}$ & $51.53 \mathrm{a}$ & $19.70 \mathrm{~b}$ & 6.05 & 5.59 & 52.26 \\
$\mathrm{~V}_{2}$ & 218.59 & 18.66 & $22.77 \mathrm{~b}$ & $139.31 \mathrm{~b}$ & $8.52 \mathrm{~b}$ & $26.50 \mathrm{a}$ & 6.01 & 5.5 & 51.48 \\
\hline $\mathrm{LSD}(0.05)$ & $\mathrm{NS}$ & $\mathrm{NS}$ & 0.591 & 7.978 & 15.150 & 0.486 & $\mathrm{NS}$ & $\mathrm{NS}$ & $\mathrm{NS}$ \\
$\mathrm{CV}(\%)$ & 23.87 & 52.98 & 1.54 & 3.38 & 32.11 & 1.34 & 5.08 & 7.80 & 4.27 \\
\hline
\end{tabular}

$\mathrm{V}_{1}=\mathrm{BRRI}$ dhan29, $\mathrm{V}_{2}=\mathrm{BRR}$ hybrid dhan2

Effect of planting material

Yield and other characters such as ineffective tillers $\mathrm{m}^{-2}$, panicle length, filled and unfilled grains panicle ${ }^{-1}$, and weight of 1000 -grains were significantly influenced by the planting 
Hore et al.

material (Table 2). The maximum (33.44) ineffective tillers $\mathrm{m}^{-2}$ was obtained from $\mathrm{C}_{1}$ which was statistically similar with nursery seedlings $\mathrm{N}(30.80)$ and the lowest (12.32) number in $\mathrm{C}_{4}$ which was statistically similar with $C_{3}$ (15.84) and $C_{2}$ (16.72). Debnath (2012) also observed highest ineffective tillers $\mathrm{m}^{-2}$ in nursery seedlings compared to clonal tillers though Ahmed (2010) found higher ineffective tillers $\mathrm{m}^{-2}$ in clonal tillers compared to nursery seedlings. The maximum $(25.72 \mathrm{~cm})$ panicle length was observed from $\mathrm{C}_{1}$ which was statistically similar with $\mathrm{C}_{2}(25.67 \mathrm{~cm})$ and nursery seedlings $(24.88 \mathrm{~cm})$, and the lowest $(23.72 \mathrm{~cm})$ from $\mathrm{C}_{4}$ which was statistically similar with $\mathrm{C}_{3}(23.92 \mathrm{~cm})$ and nursery seedlings $(24.88 \mathrm{~cm})$. Paul (1999) and Rahman (2001) found that nursery seedlings gave the longest panicles compared to the clonally propagated tillers. The maximum (171.60) number of filled grains panicle ${ }^{-1}$ was observed in $C_{1}$ which was statistically similar with $C_{2}(168.60)$ and the lowest (128.20) number in $\mathrm{C}_{4}$ which was statistically similar with $\mathrm{C}_{3}$ (139.80). The maximum (42.65) number of unfilled grains panicle ${ }^{-1}$ was observed in $\mathrm{C}_{1}$ which was statistically similar with $\mathrm{C}_{4}$ (37.83) and the lowest (19.75) number from $C_{3}$ which was statistically similar with $C_{2}(21.60)$ and nursery seedlings (28.30). The maximum 1000-grains weight (24.62 g) was obtained from $\mathrm{C}_{1}$ which was statistically similar with nursery seedlings $(24.40 \mathrm{~g})$ and the lowest $(21.60$ g) from $C_{4}$ which was statistically similar with $C_{3}(22.37 \mathrm{~g})$. The highest $\left(9.23 \mathrm{t} \mathrm{ha}^{-1}\right)$ grain yield was obtained from the nursery seedlings $(\mathrm{N})$ and the lowest $\left(2.97 \mathrm{t} \mathrm{ha}^{-1}\right)$ in $\mathrm{C}_{3}$. The yield reduction of clonal tillers than nursery seedlings was 19.39, 28.82, 67.827 and $57.62 \%$ for $\mathrm{C}_{1}, \mathrm{C}_{2}, \mathrm{C}_{3}$ and $\mathrm{C}_{4}$, respectively. The reduction of yield in clonal tillers compared to nursery seedlings might be due to the removal of tillers from the mother plant (Murthy et al., 1991). The highest $\left(8.27 \mathrm{t} \mathrm{ha}^{-1}\right)$ straw yield was obtained from the nursery seedlings $(\mathrm{N})$ and the lowest (2.82 $\mathrm{t} \mathrm{ha}^{-1}$ ) in $\mathrm{C}_{3}$. Debnath (2012), Obaidullah (2007) and Ahmed (2007) also found higher grain and straw yield in nursery seedlings than clonal tillers of first generation.

Table 2. Effect of planting material on yield and other crop characters related to yield of two rice varieties

\begin{tabular}{c|c|c|c|c|c|c|c|c|c}
\hline Treatments & $\begin{array}{c}\text { Effectiv } \\
\text { e tillers } \\
\left(\text { no. } \mathrm{m}^{-}\right. \\
2)\end{array}$ & $\begin{array}{c}\text { Ineffective } \\
\text { tillers } \\
\left(\text { no. } \mathrm{m}^{-2}\right)\end{array}$ & $\begin{array}{c}\text { Panicle } \\
\text { length } \\
(\mathrm{cm})\end{array}$ & $\begin{array}{c}\text { Filled } \\
\text { grains } \\
\text { panicle } \\
(\text { no. })\end{array}$ & $\begin{array}{c}\text { Unfilled } \\
\text { grains } \\
\text { panicle } \\
(\text { no. })\end{array}$ & $\begin{array}{c}1000- \\
\text { grains } \\
\text { weight } \\
(\mathrm{g})\end{array}$ & $\begin{array}{c}\text { Grain } \\
\text { yield } \\
\left(\mathrm{t} \mathrm{ha}^{-1}\right)\end{array}$ & $\begin{array}{c}\text { Straw } \\
\text { yield } \\
\left(\mathrm{t} \mathrm{ha}^{-1}\right)\end{array}$ & $\begin{array}{c}\text { Harvest } \\
\text { index } \\
(\%)\end{array}$ \\
\hline $\mathrm{N}$ & 224.4 & $30.80 \mathrm{a}$ & $24.88 \mathrm{~b}$ & $143.30 \mathrm{~b}$ & $28.30 \mathrm{bc}$ & $24.40 \mathrm{a}$ & $9.23 \mathrm{a}$ & $8.26 \mathrm{a}$ & 52.73 \\
$\mathrm{C}_{1}$ & 237.6 & $33.44 \mathrm{a}$ & $25.72 \mathrm{a}$ & $171.60 \mathrm{a}$ & $42.65 \mathrm{a}$ & $24.62 \mathrm{a}$ & $7.44 \mathrm{~b}$ & $6.87 \mathrm{~b}$ & 52.06 \\
$\mathrm{C}_{2}$ & 214.7 & $16.72 \mathrm{~b}$ & $25.67 \mathrm{a}$ & $168.60 \mathrm{a}$ & $21.60 \mathrm{c}$ & $22.53 \mathrm{~b}$ & $6.57 \mathrm{c}$ & $6.07 \mathrm{c}$ & 52.03 \\
$\mathrm{C}_{3}$ & 208.6 & $15.84 \mathrm{~b}$ & $23.92 \mathrm{~b}$ & $139.80 \mathrm{bc}$ & $19.75 \mathrm{c}$ & $22.37 \mathrm{bc}$ & $2.97 \mathrm{e}$ & $2.82 \mathrm{e}$ & 51.34 \\
$\mathrm{C}_{4}$ & 246.9 & $12.32 \mathrm{~b}$ & $23.72 \mathrm{~b}$ & $128.20 \mathrm{c}$ & $37.83 \mathrm{ab}$ & $21.60 \mathrm{c}$ & $3.91 \mathrm{~d}$ & $3.69 \mathrm{~d}$ & 51.20 \\
\hline $\mathrm{LSD}_{(0.05)}$ & $\mathrm{NS}$ & 12.370 & 1.216 & 14.258 & 12.617 & 0.780 & 0.59 & 0.63 & $\mathrm{NS}$ \\
$\mathrm{CV}(\%)$ & 20.28 & 46.33 & 4.01 & 7.75 & 34.33 & 2.75 & 8.09 & 9.27 & 5.44 \\
\hline
\end{tabular}

$\mathrm{N}=$ Nursery seedlings, $\mathrm{C}_{1}=$ First generation clonal tillers collected from $\mathrm{N}, \mathrm{C}_{2}=$ Second generation clonal tillers collected from $\mathrm{C}_{1}, \mathrm{C}_{3}=$ Third generation clonal tillers collected from $\mathrm{C}_{2}, \mathrm{C}_{4}=$ Fourth generation clonal tillers collected from $\mathrm{C}_{3}, \mathrm{NS}=$ Not significant

\section{Interaction effect of variety and planting material}

Yield and all other crop characters related to yield was significantly influenced by the interaction effect of variety and planting material (Table 3). The maximum number of effective tillers $\mathrm{m}^{-2}(260.5)$ was observed in $C_{1}$ of the inbred variety $\left(V_{1}\right)$ which was statistically similar with $\mathrm{C}_{2}(253.4), \mathrm{N}(241.1) \mathrm{C}_{4}$ (231.5), and $\mathrm{C}_{3}$ (184.8) of the inbred variety 
$\left(V_{1}\right)$ and $C_{3}(232.3), C_{1}(214.7)$ and $N(207.7)$ of the hybrid variety $\left(V_{2}\right)$. Lower number of effective tillers $\mathrm{m}^{-2}(176.0)$ was obtained from $\mathrm{C}_{2}$ of the hybrid variety $\left(V_{2}\right)$ which was statistically similar with $\mathrm{C}_{3}(184.8), \mathrm{C}_{4}(231.5), \mathrm{N}(241.1), \mathrm{C}_{2}(253.4)$ and of the inbred variety $\left(\mathrm{V}_{1}\right)$ and $\mathrm{C}_{3}$ (232.3), $\mathrm{C}_{1}(214.7)$ and $\mathrm{N}(207.7)$ of the hybrid variety $\left(\mathrm{V}_{2}\right)$. Debnath (2012) also observed combination of clonal tiller with BRRI dhan29 produce more effective tillers $\mathrm{m}^{-2}$ than combination with nursery seedlings of the same variety. The maximum (44.00) number of ineffective tillers $\mathrm{m}^{-2}$ was observed in nursery seedlings of the inbred variety $\left(\mathrm{V}_{1}\right)$ which was statistically similar with $C_{1}$ (33.44) of the same variety and $C_{1}(33.40)$ of the hybrid variety $\left(\mathrm{V}_{2}\right)$. The lowest number (8.80) of ineffective tillers $\mathrm{m}^{-2}$ was obtained from $\mathrm{C}_{4}$ of the hybrid variety $\left(V_{2}\right)$ which was statistically similar with $C_{2}$ (12.30), $C_{4}(15.84)$, and $C_{3}(19.36)$ of the inbred variety $\left(\mathrm{V}_{1}\right)$ and $\mathrm{C}_{3}(12.32), \mathrm{N}(17.6)$ and $\mathrm{C}_{2}(21.12)$ of the hybrid variety $\left(\mathrm{V}_{2}\right)$. Debnath (2010) also found the highest ineffective tillers $\mathrm{m}^{-2}$ in combination of nursery seedlings with BRRI hybrid dhan2. The highest $(25.72 \mathrm{~cm})$ panicle length was observed in $\mathrm{C}_{4}(28.57 \mathrm{~cm})$ of the inbred variety $\left(\mathrm{V}_{1}\right)$ and the lowest $\left((18.87 \mathrm{~cm})\right.$ in $\mathrm{C}_{4}$ of the hybrid variety $\left(\mathrm{V}_{2}\right)$.

Table 3. Interaction effect of variety and planting material on yield and other crop characters of two rice varieties

\begin{tabular}{|c|c|c|c|c|c|c|c|c|c|}
\hline $\begin{array}{l}\text { Treatment } \\
\text { s }\end{array}$ & $\begin{array}{c}\text { Effective } \\
\text { tillers } \\
\left(\text { no. } \mathrm{m}^{-2}\right)\end{array}$ & $\begin{array}{c}\text { Ineffective } \\
\text { tillers } \\
\left(\text { no. } \mathrm{m}^{-2} \text { ) }\right.\end{array}$ & $\begin{array}{c}\text { Panicle } \\
\text { length } \\
(\mathrm{cm})\end{array}$ & $\begin{array}{c}\text { Filled } \\
\text { grains } \\
\text { panicle }{ }^{-1} \\
\text { (no.) }\end{array}$ & $\begin{array}{l}\text { Unfilled } \\
\text { grains } \\
\text { panicle }^{-1} \\
\text { (no.) }\end{array}$ & $\begin{array}{l}1000- \\
\text { grains } \\
\text { weight } \\
\text { (g) }\end{array}$ & \begin{tabular}{|c} 
Grain \\
yield \\
$\left(\mathrm{t} \mathrm{ha}^{-1}\right)$
\end{tabular} & $\begin{array}{l}\text { Straw } \\
\text { yield } \\
\left(\begin{array}{c}\mathrm{t} \text { ha- } \\
1 \\
\end{array}\right)\end{array}$ & $\begin{array}{c}\text { Harvest } \\
\text { index } \\
(\%)\end{array}$ \\
\hline $\mathrm{V}_{1} \mathrm{~N}$ & & 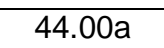 & c & $139.7 c$ & $47.67 \mathrm{bc}$ & $21.13 c$ & sa & $8.38 a$ & \\
\hline $\mathrm{V}_{1} \mathrm{C}_{1}$ & & & $26.67 b$ & $66.6 a b$ & 77.00a & $21.19 c$ & $7.23 b$ & $7.04 b$ & $50.76 a b$ \\
\hline $\mathrm{V}_{1} \mathrm{C}_{2}$ & $253.4 a b$ & 2c & $26.47 \mathrm{bc}$ & $170.4 \mathrm{a}$ & $36.90 c$ & $19.07 d$ & $6.22 \mathrm{c}$ & $5.44 c$ & $53.22 a b$ \\
\hline $\mathrm{V}_{1} \mathrm{C}_{3}$ & & bc & 26.0 & 7c & $31.23 c$ & $19.20 d$ & $3.39 \mathrm{e}$ & $2.94 e$ & 53.77ab \\
\hline $\mathrm{V}_{1} \mathrm{C}_{4}$ & b & $4 c$ & 28. & $184.0 \mathrm{a}$ & $64.87 a b$ & $17.89 \mathrm{e}$ & $4.55 d$ & $4.16 d$ & $0 a b$ \\
\hline & & & 23. & .0 & $3 d$ & 27. & $9.60 a$ & $8.18 a$ & $54.00 \mathrm{a}$ \\
\hline & & & 24. & $6 a$ & & $5 a$ & $7.67 \mathrm{~b}$ & $6.71 b$ & $6 a b$ \\
\hline & & $\mathrm{bc}$ & $24.87 \mathrm{~cd}$ & 166.8ab & o0d & $25.98 b$ & $6.94 \mathrm{c}$ & $6.72 b$ & $50.83 a b$ \\
\hline $\mathrm{V}_{2} \mathrm{C}_{3}$ & 232.3ab & $12.32 \mathrm{c}$ & $21.80 \mathrm{e}$ & $133.9 c$ & $8.267 d$ & $25.53 b$ & $2.57 e$ & $2.70 \mathrm{e}$ & 48.90b \\
\hline $\mathrm{V}_{2} \mathrm{C}_{4}$ & $262.2 \mathrm{a}$ & $8.80 c$ & $18.87 f$ & $72.43 d$ & $10.80 d$ & $25.30 b$ & $3.28 \mathrm{e}$ & $3.22 \mathrm{e}$ & $50.31 \mathrm{ab}$ \\
\hline $\operatorname{LSD}_{(0 . c}$ & 79.5 & 17.5 & 1.72 & 20.17 & 17.84 & 1.1 & .8444 & 0.891 & 4.88 \\
\hline CV (\%) & 20.28 & 46.33 & 4.01 & 7.75 & 34.33 & 2.75 & 8.09 & 9.27 & 5.44 \\
\hline
\end{tabular}

$V_{1}=B R R I$ dhan29, $V_{2}=B R R I$ hybrid dhan2,$N=$ Nursery seedlings, $C_{1}=$ First generation clonal tillers collected from $\mathrm{N}, \mathrm{C}_{2}=$ Second generation clonal tillers collected from $\mathrm{C}_{1}, \mathrm{C}_{3}=$ Third generation clonal tillers collected from $\mathrm{C}_{2}, \mathrm{C}_{4}=$ Fourth generation clonal tillers collected from $\mathrm{C}_{3}$

The maximum (184.90) number of filled grains panicle ${ }^{-1}$ was observed in $C_{4}$ of the inbred variety $\left(V_{1}\right)$ which was statistically similar with $C_{2}(170.40)$ and with $C_{1}(166.60)$ of the inbred variety $\left(\mathrm{V}_{1}\right)$ while lowest $(72.43)$ from $\mathrm{C}_{4}$ of the hybrid variety $\left(\mathrm{V}_{2}\right)$. Higher $(77.00)$ number of unfilled grains panicle ${ }^{-1}$ was observed in $C_{1}$ of the inbred variety $\left(V_{1}\right)$ which was statistically similar with $\mathrm{C}_{4}(64.87)$ of the inbred variety $\left(\mathrm{V}_{1}\right)$. The lowest (6.30) number of unfilled grains panicle ${ }^{-1}$ was obtained from $\mathrm{C}_{2}$ of the hybrid variety $\left(\mathrm{V}_{2}\right)$ which was statistically similar with $\mathrm{C}_{3}$ (8.26), $\mathrm{C}_{1}(8.30), \mathrm{N}(8.93)$ and $\mathrm{C}_{4}(10.80)$ of the hybrid variety $\left(\mathrm{V}_{2}\right)$. Debnath (2010) also observed similar result. The maximum 1000 -grains $928.05 \mathrm{~g}$ ) was obtained from $\mathrm{C}_{1}$ of the hybrid variety $\left(V_{2}\right)$ which was statistically similar with nursery seedlings $(27.66 \mathrm{~g})$ of the hybrid variety $\left(\mathrm{V}_{2}\right)$ and the lowest $((17.89 \mathrm{~g}))$ from $\mathrm{C}_{4}$ of the inbred variety $\left(\mathrm{V}_{1}\right)$. Among the treatments, the maximum $\left(9.60 \mathrm{t} \mathrm{ha}^{-1}\right)$ grain yield was observed in nursery seedlings of the 
Hore et al.

hybrid variety $\left(\mathrm{V}_{2}\right)$, which was statistically similar with nursery seedlings (8.86 $\mathrm{t} \mathrm{ha}^{-1}$ ) of the inbred variety $\left(V_{1}\right)$. The lowest $\left(2.57 \mathrm{t} \mathrm{ha}^{-1}\right)$ grain yield was observed in $\mathrm{C}_{3}$ of the hybrid variety $\left(V_{2}\right)$ which was statistically similar with $C_{4}\left(3.28 \mathrm{t} \mathrm{ha}^{-1}\right)$ of the same variety $\left(\mathrm{V}_{2}\right)$, and with $\mathrm{C}_{3}\left(3.39 \mathrm{t} \mathrm{ha}^{-1}\right)$ of the inbred variety $\left(\mathrm{V}_{1}\right)$. Higher straw yield $\left(8.36 \mathrm{t} \mathrm{ha}^{-1}\right)$ was observed in nursery seedlings $(N)$ of the inbred variety $\left(V_{1}\right)$, which was statistically similar with nursery seedlings $\left(8.18 \mathrm{t} \mathrm{ha}^{-1}\right)$ of the hybrid variety $\left(\mathrm{V}_{2}\right)$. The lowest straw $\left(2.70 \mathrm{t} \mathrm{ha}^{-1}\right)$ yield was observed in $\mathrm{C}_{3}$ of the hybrid variety $\left(\mathrm{V}_{2}\right)$ which was statistically similar with $\mathrm{C}_{3}\left(2.94 \mathrm{t} \mathrm{ha}^{-1}\right)$ of the inbred variety $\left(\mathrm{V}_{1}\right)$ and $\mathrm{C}_{4}\left(3.22 \mathrm{t} \mathrm{ha}^{-1}\right)$ of the hybrid variety $\left(\mathrm{V}_{2}\right)$.

\section{Conclusion}

The results of the experiment revealed that the yield of rice was identical between the inbred variety $B R R I$ dhan29 and hybrid variety $B R R I$ hybrid dhan2 though the crop grown from nursery seedlings produced the highest yield over that from the clonal tillers of successive generations. The highest grain yield and harvest index (9.60 $\mathrm{t} \mathrm{ha}^{-1}$ and $54.00 \%$, respectively) were observed from nursery seedlings of BRRI hybrid dhan2 and the lowest from third generation clonal tillers of BRRI hybrid dhan2 $\left(2.57 \mathrm{t} \mathrm{ha}^{-1}\right.$ and $48.90 \%$, respectively). So the clonal tillers can be used up to second generation with little sacrifice of yield irrespective of inbred and hybrid rice.

\section{References}

Ahmed, Q. N. and P. K. Biswas. 2010. Different cultivation methods of paddy: New scopes for Bangladesh, A comparative study of different cultivation methods on inbred and hybrid rice. VDM Verlag Dr. Muller Aktiengesellschaft \& Co. KG, Dudweiler Landstr. 99, 66123 Saarbrucken, Germany.

Ahmed, Q. N., P. K. Biswas and M. H. Ali. 2007. Influence of cultivation methods on the yield of inbred and hybrid rice. Bangladesh J. Agric. 32(2): 65-70.

Alim, M. A. and M. S. Sheuly. 2012. Effect of time of tiller separation on grain growth and seed yield of transplant aman rice. J. Sci. Found. 10(1): 12-19.

Anonymous. 1988. The Year Book of Production. FAO, Rome, Italy.

Anonymous. 2004. Annual Internal Review for 2000-2001. Effect of seedling throwing on the grain yield of wart land rice compared to other planting methods. Crop Soil Water Management Program, Agron. Division, BRRI, Gazipur.

Ashrafuzzaman, M. 2006. Influence of tiller separation days on yield and yield attributes of inbred and hybrid rice. M.S. Thesis. Dept. of Agron., SAU, Dhaka.

Babiker, F. S. H. 1986. The effect of zinc sulphate levels on rice growth and productivity. Alexandria J. Agril. Res. 31(2): 480-481.

Bari, S. M. W. 2004. Effect of method of planting and weeding on the yield and yield contributing characters of aman rice cv. BRRI dhan 32. M. S. Thesis. Dept. of Agron., BAU, Mymensingh.

BBS (Bangladesh Bureau of Statistics). 2008. Statistical Yearbook of Bangladesh for 2008.

BBS (Bangladesh Bureau of Statistics). 2011. Statistical Yearbook of Bangladesh for 2011. 
Yield of Inbred and Hybrid Rice as Affected by Clonal Tillers of Successive Generation

Biswas, P. K. 2001. Tiller dynamics and yield of parent and clonal plant of transplanted rice. Doctoral Dissertation. School of Environment, Resources and Development, AIT, Thailand.

Biswas, P. K., and V. M. Salokhe. 2001. Effects of planting date, intensity of tiller separation and plant density on the yield of transplanted rice. J. Agril. Sci. Camb. 137(3): 279-287.

BRRI, 2011. Bangladesh Rice Knowledge Bank. Internet Edition. http://www.knowledgebankbrri.org/riceinban.php. Accessed in December, 2011.

Debnath, A. 2010. Influence of planting material and variety on yield of boro rice. M.S. Thesis. Dept. of Agron., SAU, Dhaka.

Debnath, A., P. K. Biswas, M. S. A. Sardar and A. Rahman. 2012. Influence of mother and clonal tillers on yield and performance of inbred and hybrid boro rice. Bangladesh Agron. J. 15(1): 1-7.

Donald, C. M. 1963. Competition among crops and pasture plants. Adv. Agron. 15: 11-18.

FAO (Food and Agriculture Organization). 2013. FAO Statistics. Internet Edition. http://faostat.fao.org/site/339/default.aspx. Accessed in October, 2013.

Gardner, F. P., R. B. Pearce and R. L. Mistechell. 1985. Physiology of Crop Plants. lowa State Univ. Press, Powa. p. 66.

Gomez, K. A. and A. A. Gomez. 1984. Statistical procedure for agricultural research. $2^{\text {nd }}$ Edn. Intl. Rice Res. Inst., John Wiley and Sons. New York. Pp. 1-340.

Hossain, M. A., M. A. R. Sarkar and S. K. Paul. 2011. Growth analysis of late transplant aman rice (cv. BR23) raised from tiller seedlings. Libyan Agric. Res. Cen. J. Intl. 2(6): 265-273.

Hossain, M., A. Janaiah and M. Husain. 2003. Hybrid rice in Bangladesh-Farm level performance. Economic and Political weekly, June 21.

IRRI. 2013. Internet Edition. http://irri.org/our-impact/increase-food-security. Accessed in August, 2013.

Julfiquar, A. W., S. S. Virmani., M. M. Haque., M. A. Mazid and M. M. Kamal. 2009. Hybrid rice in Bangladesh: opportunities and challenges. Rice research for food security and poverty allevation. Proc. Int. Rice Research Conference.

Main, M. A. 2006. Influence of planting material and planting methods on yield and yield attributes of inbred and hybrid rice. M.S. Thesis. Dept. of Agron., SAU, Dhaka.

Mamun, M. A. A., R. Shultana., B. C. Roy., M. M. Rana., A. Parvez and A. J. Mridha. 2012. Effect of transplanting with separated tillers and planting time on the performance of boro rice. Bangladesh Agron. J. 15(2): 83-88.

Mondal, M. R. I. and D. A. Choudhury. 2014. Agronomic Visions for Sustainable Food Security. Keynote paper presented at the $13^{\text {th }}$ Biennial Conference of the Bangladesh Society of Agronomy. Pp. 26-29.

Murthy, P. S. S., P. J. R. Reddy and S. S. R. Prasad. 1991. Effect of grain yield of shoot removal at different stage of aman rice crop growth. Intl. Rice Res. Newsl. 16(3): 10.

Obaidullah, M. 2007. Influence of clonal tiller age on growth and yield of aman rice varieties. M.S. Thesis. Dept. of Agron., SAU, Dhaka.

Parveen, S., M. P. Anwar., S. M. A. Hossain., L. H. Abru and T. Yeasmin. 2008. Yield ability of tillers separated from T. aman rice cv. BRRI dhan41. J. Agrofor. Environ. 2(2): 171-175. 
Hore et al.

Paul, S. K. 1999. Effect of row management and tiller separation on the growth and yield of transplant aman rice. M.S. Thesis. Dept. of Agron., BAU, Mymensingh, Bangladesh.

Rahman, M. S. 2001. Effect of tiller plantation on the performance of transplant aman rice. M.S. Thesis. Dept. of Agron., BAU, Mymensingh, Bangladesh.

Sarkar, M. A. R., M. A. Hossain and S. K. Paul. 2011. Effect of row arrangement, age of tiller seedling and number of tiller seedlings per hill on performance of transplant aman rice. J. Agric. Sci. 6(2): 59-68. 